\title{
The Semantic Structure of Color Terms in Arabic: A Cognitive Approach
}

\author{
Jinan Al-Tamimi \\ Department of Arabic Language, Prince Sattam bin Abdulaziz University, Saudi Arabia
}

\begin{abstract}
The acquisition of the ability of perceiving and naming colors through language is an important topic in which languages vary and differ. The construction of color concepts and naming them are directly influenced by the culture and environment of each society. This can be noted by observing two aspects: Cognitive Semantics and its effect on the collective mind. This study focuses on the cognitive foundations of color terms in Arabic, and the semantic relation between the color concepts and terms in selected examples from both old and new usage of these color terms in Arabic. The study aims to cover the most dominant semantic components for color terms in the Arabic language, using the cognitive linguistic approach and the descriptive analytics method to determine the structure of cognitive perception of color terms in a language. Furthermore, the study stands on two pillars; the first reveals the way the conceptualization pattern of color terms occurs in Arab mindset displayed through selected examples of theoretical data on cognitive semantics, whereas the second addresses the semantic principle of color classification in Arabic. Finally, the conclusion, confirming the results about the notion that color naming in Arabic is based on the visual images associated with the colors in Arab environment, related to night and day. Hence, the color term becomes connected in the Arab mindset with the visual image, and under each color are colors similar to it in hue.
\end{abstract}

Index Terms - cognitive semantics, categorization, prototype, metaphor

\section{INTRODUCTION}

Some linguistic and cultural problems are related to our perception, categorization, and naming of colors. The universe, including its nature, human beings, languages, and distinct cultures, is a comprehensive subject that cannot be studied by linguistics alone; studying it is also not limited to the physical sciences alone. The humanities and physical sciences must work together to understand the language use aspects and their interpretation. This research represents a viewpoint based on the way in which the colors are expressed in Arabic language. Accordingly, this research studies the perceptual horizons for color terms in Arabic regarding semantic data relating the use of color terms "Ahmer (red), Asfar (yellow), Akhdhar (green), Azrag (blue), Abiyadh (white), and Aswad (black)," and discusses the semantic meaning of colors in Arabic regarding the semantic structure of colors, their classification, and their names.

This paper deals with the problem of the cognitive semantics of colors in Arabic, based on the cognitive sciences of linguistics. This is to reach a conceptual structure through which the meanings of color terms in Arabic language are formed, which in turns depends on the metaphorical perception of meaning first and the principle of classification or category second. Color metaphors in Arab culture are not limited to language alone, but they are found in our thinking, and in our classification of things around us. Language is an important source of evidence of how the conceptual system of vocabulary connotations operates in Arab mindset. This is based on the linguistic data of the use of color terms in ancient and contemporary Arabic. The views that we promote in this research have directly influenced by the linguists Lakoff \& Johnson on the one hand (Lakoff \& Johnson, 2009). and by what Eleanor Roch called the theory of prototypes and basic-level classes on the other hand (Rosch, 2013).

Cognitive Semantics

It is meant by semantics "the study of meaning", but the question that arises in this area is (what is the meaning?) Philosophers have discussed this question, and none of them provided a sufficient answer to it, and one of the reasons for the difficulty of answering such a question may be its formulation, as it raises two presupposition: The first is that what we refer to with the word 'meaning' is some kind of existence or reality; and the second is that what is referred to as meaning is similar in nature to what is in existence or reality, and we may call these, respectively: the presupposition of existence, and the presupposition of homogeneity (Lyons, 1987).

The literal semantic theory explains how the reference and the value of truthfulness related to linguistic expressions. It is the way that is expressed by common sense, whereby the words say something about the world. When I say, "A tree has red leaves," I am referring to a type of tree that exists in the real world (red maple). When I point to something specific and say, "This is a tree," the demonstrative pronoun "this" refers to something in the world that was pointed to. Intuition also requires that sentences have truth-values because of how they relate to the world. A sentence such as "My name is Sarah" is a truthful sentence if a female named 'Sarah' said it and is an untruthful sentence if a female said it, her name is not 'Sarah'. Thus, the processing of linguistic meaning is related to the relationships that the language 
establishes with what exists outside of it; Language has the property of referring to properties or things outside of it. Meaning located in the interaction between living things and their environment (Ghalim, 2010)).

Understanding the meaning of color accurately and specifically is an issue that is neither easy nor simple, as the meaning is a mental image that appears only as a coding in the color terms. The area of meaning includes the relationships of the terms to each other on the one hand, and the relationships of these terms with the outside world on the other hand. Colors are one of the basics of sensory perception, which are key factors in human communication, but for humans: Are the concepts of "yellow" or "green", as example, universal constants of humanity? In the sense that the biological makeup of the eye and brain are what shapes the concept of these colors, or that the culture and the surrounding environment shapes the concepts of colors in every human society in a unique way. Language does not express concepts accurately, meaning that there is no clear and specific list of the concepts and their corresponding names. "Language, in order to be able to convey accurate ideas that involve complex relationships between different concepts, needs much more than a list of concepts." (Deutscher, 2015))

We can arrive at a meaning close to accuracy in the context of a cognitive semantic theory that considers natural language a mental representation, where the meaning that language conveys is shaped by the way the mind organized the experience. This information, which is manifested in linguistic representations, cannot refer to the real world but to projected world is the result of this structure and the product of mental organization. If language has a connection with the world outside, then it is through the mediation of perceptual systems, such as the visual system and auditory system, and not through a mysterious relationship between the mind and the world, such as the intentional relationship or something else (ibid).

\section{The perception system of color terms semantics in Arab mindset}

Color in Lisan Al-Arab book by Ibn Manzoor (1993, p. 585) is defined as "a (form/shape property), such as asSawad (blackness) and Al-Humarah (redness). The color of a thing is what distinguishes it from others". The definition of color here shows us the direct relationship between color, darkness, and light. The boundary that draws the line between things and gives them their visible form is the color. Color cannot be perceived in darkness, and it can only be perceived in the presence of light.

The cognitive semantics using the data of cognitive psychology explains the mind mechanism of understanding the meaning of color terms. The human visual memory represents visual information by modeling its components and external characteristics. Language provides us with data that can lead to general principles for understanding the meaning of each color term. These principles require not separate words or individual perceptions, but whole systems of perceptions. Also, these principles are often of metaphorical nature, requiring an understanding of the meaning of for example, 'blackness' through human experience with darkness, or the absence of light. We perceive 'whiteness' in a natural metaphorical way through light. Our natural perceptions are naturally reflected in our linguistic expressions. So Akdhar (green) means good and prosperity, Aswad (black) means dark and bad, and Abyidh (white) means light and purity.

The problem of color perception is related to the local culture. In a study conducted by Brent Berlin and Paul Kay on color perception, when they compared common color terms in different cultures (European, Asian, African, and American), they went on to say that there is a group of names, depending on the nature of the languages and the people's lives. If some of these languages and peoples have a rich or poor list of color terms, they, for example, may be characterized by a clear dominance of semantics of 'white' color versus a lack of semantics of 'green' color or vice versa. This sensitivity towards colors is relevant to peoples' lifestyles. The inhabitants of the Arctic possess in their language dictionary a wide range of color terms for white because they are living all year round in a snowy and icy environment, while the Amazon Indians who live in the midst of the forests have a series variety of names that are especially related to the colors green and brown (Aharchaou, 2002). In the Ethiopian language, the meaning of colors is associated with the objects in nature. The color white is expressed by the words for milk, ash, foam, ice, and cotton. Black is described as darkness, charcoal, and jinn/devil. Red color is associated with blood, fire, amber, pepper and dusk. The green color is described by words derived from tree leaf, cabbage and grass. The yellow color is taken from flower, yolk, banana, and honey (Leyew, 2016).

As a cognitive being, the speaker has the visual experience of colors that appear in the environment in which he lives. Here, the concept of visual experience does not refer specifically to the individual experience of a specific person, but rather the experience that we, as human beings are living on the surface of the earth, agrees upon and interacts about it with the community. It is also an active changing element that is affected by the changes of humans and their interaction in their natural, social, and cultural surroundings. The human mind is thus instrumental in determining the semantic perceptions of colors, and in creating new semantic perceptions as well. (Lakoff \& Johnson, 2009).

To build a correct perception of the semantic meaning of color terms in the Arabic, a multidimensional approach that considers linguistic and non-linguistic indicators is required. This is because human mind is not neutral; it is directly affected by human experience, one of the most important elements of which is the human possession of an erect body with a head and eyes affected by light and color. In addition, the meaning is related to an imaginary projection using category and metaphor. Perhaps, the best quote to illustrate the use of color terms in Arabic language is what Safi alDin al-Hilli said after he took his revenge: 


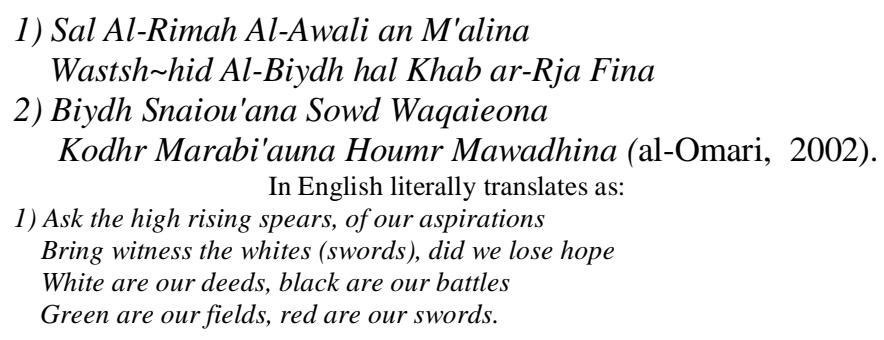

"Whites" in the first poetic verse mean "swords", and the Arabs in the past called the sword "white". "White weapon" is currently defined as "every tool that is incisive, perforating, shattered or bruising tool, such as swords, daggers, arrows, lances, harpoons, bayonet sticks with a spear and fists, and the like". According to the Saudi Weapons and Ammunition Regulation issued on 08/30/2005, while "whites" in the second poetic verse is a metaphor for the good deeds (favours), "black are our battles" is a metaphor for wars, "green are our fields" is a metaphor for goodness and prosperity, and "red are our swords" is a metaphor for many killings. Here, the target domain, which is the events from (deeds, wars, goodness, and courage), for the poet, is associated, respectively, with the source domain, which is the color terms (white, black, green and red). Since the concept of (color) is used to build the concept of (event) by depicting it with concepts and relationships derived from the color domain.

Al-Aswad (Black): Arabic dictionaries define color terms by providing a general analysis of how people understand colors, or define a color by its opposite, or through systemic metaphors such as: al-Aswad (black) is dark, Al-Abiadh (white) is purity, and al-Akhdhar (green) is prosperity, and al-Ahmar (red) is the 'Ajami (an Arabic word meaning mute, which refers to someone whose mother tongue is not Arabic), or al-Aswad (black) is jinn/devil and as-Sawad (blackness) is the majority.. etc. Ibn Manzoor says in section of the letters (Sein Waw Dal [ [ w a [in English = s w d], "as-Sawad (blackness) is the opposite of al-Baiyadh (whiteness) ... and Sawad al-Qawm (literally=the blackness of people) is the great majority of people." Here, he first defined color by comparing it to its opposite, then borrowed the color term to describe the great majority of people.

In another context, Ibn Manzoor cites the word Ahmar (red), with a hadith narrated on the authority of Abu Dharr that he heard the Prophet (may Allah's peace and blessings be upon him) say "I have been given five things which were not given to any amongst the Prophets before me: I was sent to the Ahmar (red) and the Aswad (black), and I have been made victorious with the awe from a one month distance ..etc". Then, in his interpretation of the meaning of these twocolor terms in this context, he quotes Shammar's saying: "It means Arabs and Ajam (non-Arabs)." He explains this by that the skin color of Arabs was primarily known to be as-Sumrah (brown) and al-Adamah (dark brown) whereas the non-Arabs were known to be al-Baiyadh (white) and al-Humrah (reddish). Here we notice that the explanation of the description combines the names of the colors that are close to the semantic field of "black", which are (as-Somrah [brown] and al-Adamah [deep brown]), and the names of the colors that are close to the semantic field of "red", which are (al-Baiyadh [white] and al-Humrah [reddish]). Here we can understand the direct similarity relationship between 'red' and 'redness' colors. But it is difficult to explain the similarity relationship between red and white colors! This will be shown later in the semantic cognitive analysis of the contexts of using these two-color terms in Arabic usage. It is difficult to completely distinguish between the literal and the metaphorical use of color terms. In another interpretation of the meaning of the above-mentioned hadith that: The Prophet meant humans and jinn, as it was narrated on the authority of Abu Mashal that he said about the Prophet's saying "I was sent to the Ahmar (red) and the Aswad (black)": that the Prophet means by black 'the jinn', and by red 'the humans'. He explained the reason for the naming of 'humans' as 'red' by the blood that is in them and leaves the reason for the naming of 'jinn' as 'black' without explanation. This is maybe because that the two terms 'jinn' and 'black', in the Arabic usage, have the same semantic meaning. This is because the origin of the meaning of the word "jinn" (by doubling the letter 'Noon') is "hide a thing; it is hidden, which means cover it. Everything was hidden from you, it was covered from you. Night descend: it is so dark and became so black."(Ibn Manzoor, 1993) Here it becomes clear how the term 'black' acquired its meaning. The similarity between black and covering something from your sight and the darkness of the night is clear.

The color term 'black' acquired its semantic meaning in the Arab environment, which first knew black color in the darkness of the night, and then used it as a metaphor for things which resembles it in color. Everything is in darkness and its color and shape disappeared, even partially, is called 'black'. It is said: "Asawd An-Nas (literally meaning black people) passed by us, it is meant by 'black people' a person, because a person from afar is seen black (ibid) as-Sawad (literally the blackness) is the group of palms and trees for their greenish and dark in color. It was said: this is because greenness is close to blackness (ibid). Thus, we notes that the use of 'black' term extended to meanings other than the basic meaning. Dark or deep colors are called Aswad (black). According to the scientific classification of colors, white and black colors are not included in the color classification. 'Black' and 'white' terms are metaphors for expressing light and darkness in real life. When we enter a well-lighted place, we do not say this place is 'white', rather, we say it is Modha'a (lighted). According to Al-Skafi (2018) when we enter a dark place, we do not say this place is 'black', rather, we say it is Modhlim (dark). The use of white term or black term here is to indicate the degree of brightness or the degree of darkness of a color. Therefore, the green or red or dark blue color, are called by the Arab, black. 
As for the use of the meaning of the term black in the context of modern Arabic language, it appears in many verbal correlatives that show us the cognitive dimensions of the meaning of 'black' term (Aswad) in the modern Arabic context. It is meant by verbal correlation "the words that stick and join together to form units that are frequently used and circulated among people, then the words forming these units do not come to mind individually, but as holistic units that are often distinguished by being intuitive and having fixed structures (Haji \& Ibrahim, 2018). This includes the 'black' term, which is verbally associated with contexts of resentment of actions, events, or persons. For example, when the supplication is made against a person who has done a disgraceful act, it is said: Sawad Allah Wajhak meaning "May Allah make your face black". On the other hand, if a person has done a good deed, it is said: Baiydh Allah Wajhak meaning "May Allah make your face white." A day that carries with it a bad event is called "Tarikh Aswad meaning (A Black History), Ayam Sawda'a meaning (Black Days), and Safha Sawda'a meaning (a Black Page)," and it is said Aihfadh Qirshak Al-Abiyadh lil-Yawm al-Aswad meaning (Save Your White Money for the Black Day.) 'White Money' is used as a metaphor for prosperity, and 'Black Day' is used for a metaphor for the day of poverty and need. Malafah Aswad meaning "He has a 'black' file" is said about a person with bad deeds, and Qalbah Aswad meaning (His heart is black) is said about the person with malicious intents. The market in which illegal goods are traded is called a Swq Sawda'a meaning (black market). And for the only small bad deed among a lot good deeds, it is said: Nuqtah Sawda'a meaning (A black dot in a white paper), and Nadharah Sawda meaning (Black glasses) is metaphor for pessimism.

When looking at the contexts in which the supplication "May Allah make your face white", we can easily notice that this supplication is not limited to praying for people with a specific skin color; It is completely unrelated to skin color; but rather it is related to feelings of pride and for the person to be known among people with good deeds. From afar, in Sawad Al-Nas meaning (the crowd of people), a person cannot be known. This is because the person cannot be recognized or seen with a large number of people or because it is difficult to know the identity of the person or see his features as a result of the distance. Therefore, we pray for people of all skin colors by saying: "May Allah make your face white," meaning, "May Allah makes you known among people by doing good deeds."

Abiyadh (White): According to Lisan Al-Arab book, 'al-Bayadh' (whiteness) is the opposite of 'as-Sawad' (blackness); the color Abiyadh (white) can be found in animals, plants, and other similar things. In a hadith of the Prophet (PBUH) he said: "I have been given the two treasures: Al-Ahmar wa Al-Abiyad meaning (the red and the white)." The 'red treasure' refers to the kingdom of the Levant and the 'white treasure' refers to the kingdom of Persia. The people of Persia are referred to by the color term Abiyadh (white), either because most of their money was silver, or because of the whiteness of their skin. The people of the Levant are referred to by the color term Ahmar (red), either because most of their money was gold, or because of the redness of their skin.

The most hated thing for an Arab was to have a child born to him from his female slave wife, and this is according to what was reached by Yusef Khalif (1959). Sometimes the Arabs enslaved their children from their female slave wives, and refused to recognize them. The worst luck and the lowest social standing among those half-breeds were the children born of black female slave wives who inherited blackness from their mothers. The Arabs hated black as much as they loved white (Khalif, Yusef. (1959). Quotes: "Biydh Al-Wojwh Bani Am wa Ikhwan" (literally meaning: Their faces are white they are cousins and brothers)." (Al-Jamhi, n.d). "Biydh Al-Wojwh ala Al-A'dw Thiqal (literally meaning: Their faces are white*they are heavy on

the enemy) Al-Muthanna, (1998). In Surat Al-Imran (verse: 106) "On the Day [some] faces will turn Abiyadh (white) and [some] faces will turn Aswad (black)." (in this verse "white" is a metaphor for radiant and shining) "The inhabitants of Paradise are marked by their white faces"(Al-Tabari, (2001). However, this does not mean that Arabs describe a white face as a sign of beauty only, but rather used it in the context of pride in beauty as well as purity of reputation. And "their faces are white is meant they did not commit shameful acts that would bring shame upon them." (Al-Muthanna, n.d) Thus the meaning of the term white here relates to the concept of a person known for purity of reputation. Among these are the poetic verses of Hassan bin Thabit in praise of the family of Jaffna: (Al-Qurashi, 1981).

$$
\begin{aligned}
& \text { 1) Bid Al-Wujoh Karimatn Ah-Sabuhum** Shum Al-'Onoofi mi al-Tirazi al-Awali } \\
& \text { 2)Yughshawn Hata ma Tahir Kilabuhum ** La Yas'alwon an as-Sawad al-Muqbili } \\
& \text { In English literally translates as: } \\
& \text { 1) Their faces are white and they are noble descent ** Their noses are high and they are first-class } \\
& \text { ('white faces' here refers to purity and chivalry/generosity) } \\
& \text { 2) Many people come to them, so that, their dogs no longer bark ** } \\
& \text { They do not ask about the blackness of people coming to them } \\
& \text { ('blackness of people' here refers to a large number of people) }
\end{aligned}
$$

In the Holy Quran text, the Abiyadh (white) color term was mentioned twelve times in the contexts of referring to the divine power, describing the drink of the people of Paradise, the reflection of good deeds on the faces of the righteous people of Paradise, and explaining the temporal meaning associated with acts of worship. In Surat Yusuf (verse 84) "his eyes became white from grief", the 'white' term turns into a pathological state to denote the extent of the calamity (AlJahiz, Amr. n.d). It should be noted that the Arabs did not always prefer the white color. It was preferred except for eye color and hair color. The eye does not become white except from grief and disease, and hair color turning white is a sign of aging and elderliness. If the Arabs say so-and-so (male) is white or so-and-so (female) is white, then the meaning is that the purity of his/her honor and he/she did not do a disgraceful act. If the Arabs, about so-and-so (male) 
or so-and-so (female), say his/her face is Abiyadh (white), they mean the purity of his/her face color from freckles/wrinkles and pimples (Ibn Manzoor, n.d).

The Arabs also say Al-Ayam Al-Baidh (the white days), so they use the term 'white' as a description of the days in the middle of the lunar month when the moon is full and bright. They are the nights of thirteen, fourteen, and fifteen of every lunar month. "Among the white nights is the thirteenth night of every lunar month, and Arabs said: Affra Night"(Qutrub, 1985). It is meant by 'Affra Night' the thirteenth night of every lunar month. "Al-'Afar" (an Arabic word from which the word Affra is derived=dust in English) is "the top soil", its color is "red-dust". 'A'afar antelope: it is a type of antelope with a white-reddish color (Arabian gazelle). "Aufrah" meaning is a white color but is not an extremely bright white. It is a color close to the color of the earth's surface (Ibn Manzoor, 1993). This includes the saying of the Arabs: "They had Al-Baydha'a (the white one) and Al-Sawda'a (the black one) (Ibn Abd Rabbo, 1983) Al-Baydha'a is the dry area of land without vegetation, and Al-Sawda'a is the very green area of land with trees and plants.

Ahmar (Red): According to Lisan Al-Arab book: "al-Humrah (redness): It is a well-known middle color"(Ibn Manzoor, 1993). The intermediate colors, in the words of the Arabs, are the colors ranged between black and white. AlBiruni says: "As for the intermediate colors, they are the colors between the bright white and dark black tracts in the mountains"(Al-Biruni, 1990). In Arabic dictionaries, we find the word Ahmar (red) is used to refer to words that can be regarded as synonymous metaphors, such as al-Nabid (wine), al-Lahm (meat), and ad-Dam (blood), or in entries referring to death, life, gold, and saffron. Dictionaries do not indicate how we understand the term Ahmar (red) from these synonymous metaphors, or how people understand the meaning of the color red, and they do not clarify how to distinguish the boundaries that separate between its semantic meanings for red color and yellow color. Perceptions that are used through metaphors to define other color perceptions in turn correspond to natural species in human experience. If we look at the light saffron water, we will see it is yellow. While before soaking it in water, its color is a bit red. Therefore, you find that saffron in some places is mentioned to refer to things of yellow color, and in other places to refer to things of red color.

Ibn Faris (395 AH) quoted from the Arabs that they said: "Al-Hussn (beauty) is Ahmar (red)". He explains: "AlHumrah (rosy white skin woman) is not hated by almost all souls." And their saying about the rain that: "Gaith Himro" (literally: red rain = heavy rain), if it was raining extremely hard, and the rain sweeped the lands away (Ibn Faris, 1979). Naming the rain as "Red Rain" is taken from the Arab environment, as the dry land color is light red with white (Affra), and if a heavy rain falls on it, its color turns to red brown, so they called it "Gaith Ahmer" literally meaning red rain AnNaka': An Arabic word that describes everything red. Al-Nak'ah (singular of An-Naka' in Arabic): An Arabic name for a fruit tree of some kind, its produce is red (Ibn Saidah, 2000). In our words today, we say: "Ahmer Nāqi'a" meaning "very red". And we say "Mawt Ahmar" (literally: A Red Death); "Mawt Ahmar" means "the violent death by murder." This is because, in this type of murder, a lot of blood is spilled, which is red in color. "Mawt Ahmar" as a metaphor may be used to refer to the severity of death in the war. Abu Zaid Al-Tai says in describing the lion:

Ida 'Alqat Qarnan Khatatif Qarnih ** R'aa Al-Mawt Rai Al-Ain Aswada Ahmar

In English translates literally as:

(When it [the lion], by the claws of its paw, catches a prey's horn

**It [the prey] will see with its own eyes the black and red death meaning (it will inevitably die))

"It (the prey) will see with its own eyes the black and red death"; the poet said, "with its own eyes", as an affirmation. Because death cannot be seen by itself with the eye, he then said, "the black and red death". Black and red are colors, which are not seen except by the eye. He portrayed death as a visible thing, so we could understand it (Ibn Saidah, 2000). Black is the color of the unknown, death is black, and red is the color of blood. Therefore, the color term Aswad (black) is always associated with death and fear, and the color term Ahmar (red) is always associated with death caused by murder.

Akhdhar (Green): According to Lisan Al-Arab book: "al-Khudhrah (greenness): It is a color; the color Akhdar (green) can be found in animals, plants and other similar things. Ibn al-'Aarabi said that, the color term Akhdar (green) is used to describe the water as well. Green water is water that is greenish in color because of its purity. Allah the Almighty said: "fatusbihu al-ardu mukhdarratan" meaning "Do you not see that Allah has sent down rain from the sky and the earth becomes green?" (Quraan) Akhdar (green) is a color between Abiyadh (white) and Aswad (black), and it is closer to black. This is why Akhdar (green in color) is referred to as Aswad (black in color) and vice versa. "Sawad Al-Iraq meaning (Blackness of Iraq)", is said for a place where greenery abounds (al-Isfahani, 1992) Al-Khuadra (greenness/dark green) was called Al-Dahmah in Allah Almighty's saying: "Mudhammatani" (Quran), meaning (two gardens are dark green [in color].)

A person with Aswad (dark brown) skin color may be called Akhdar (green). Al-Khudr: It is an Arab tribe, so named because of (Khodhrat Alwanihim) meaning (the greenish color of their skin (Al-Zubaidi, 1965). By 'greenish' in people's colors, he means: dark brown; Al-Lahabi says:

\section{Wa Ana Al-Akhdhar mn Y'arifuni?***Akhdar Al-Jildat fi Baiyt Al-Arab \\ This translates literally as follows: (I am Al-Akhdar (the green man), who knows me? *** A man with green skin color from the house of the Arabs)}

By his words "I am Al-Akhdar" meaning (I am a man with dark brown skin color), he wants to say that he is from a pure Arab race because the skin color of Arabs was primarily known to be as-Sumrah (brown)" (Al-Jawhari, 1990). Ibn Berri says: "By Al-AKhdhar "green" he meant that his skin color is brown, but by this he wants to point to the purity of 
his lineage, and that he is of pure Arab race, because the early Arabs describe their colors as 'dark brown/blackness' and the colors of the non-Arabs as 'red/redness'". "Banu Khudayr (literally meaning the descendants of greenish man): They are those who were born of black and white parents"(Kahala, 1994). Here we notes that the green color ranges from white-green to black-green, and the darker it becomes, the Arabs call it black.

Asfar (Yellow): According to Lisan Al-Arab book: "al-Sufra (yellowness): It is a color; the color Asfar (yellow) can be found in animals, plants and other similar things. Ibn al-'Aarabi said that, the color term Asfar (yellow) is used to describe the water as well." Here we see that the yellow color, according to Ibn Manzur's description, can be seen in everything, animals, plants, and water as well. In the Arabs mindset, it is associated with things in which the yellowish color appears.

On the other hand, there is a cultural perception of the color term Asfar (yellow), as it is found in the plant, when it dried out, it will be seen dry and yellow after its liveliness and greenness. Allah the Almighty Said: "fatarahu musfarran" meaning "then they (the plants) dry and you see them turned yellow." (Quraan). This means that when the plants dry out, you will see them dry and yellow after their liveliness and greenness. If the plant dries out, it turns from green to yellow (al-Tabarī, n.d). The Arabs called the Romans, "Banu al-Asfar". "Banu al-Asfar: Romans of Byzantine" (Ibn Manzoor, 1993). Here we are confused, and it is difficult for us to understand the reason for why the color of Byzantine Romans described as yellow? Is it because of the color of their skin, or the color of their hair? Or is it because thatan Abyssinian fathered children from a Roman woman, and these children inherited the whiteness from the Byzantine Romans and the blackness from the Abyssinian, so they were yellow and black in color? Or is it because they have descended from the Abyssinian and the Arabs for the person with Aswad (dark brown) color skin, they called him the Asfar (yellow)?

(Al-Katani, 1981). Here, the semantic meaning of the color term Asfar (yellow) is a local related to the Arab cultural context. Therefore, the Arab can understand that "as-Sufrah (yellowness) also means as-Sawad (blackness)." (Ibn Saidah, 2000). This is what Al-Fara explains by saying: "Al-Sufr (the yellow ones): the black camels. When you see any black camel, you will see that it is yellowish in color, and this is why 'the camels with black color' were called by the Arabs, 'Al-Sufr (the yellow ones)'." (Al-Azhari, n.d). The yellow color with its tones that ranges from golden to red appear in the Arab environment in saffron and gold, which are called: "Al-Asfaran (the two yellow things)." (AlZubaidi, 1965). Here, we find that the semantic meaning of the two color terms black and yellow was formed from a visual image derived from the Arab environment through a single object, which is (the camel), because the black camels are always imbued with some yellow. The visual image of the black camel determined the semantic meaning of the color term Asfar (yellow) as referring to the black color. The semantic meaning of a color term is thus formed through another color term.

The degrees of the color yellow in the Arab cultural context also named as follows: "Light yellow, close to white, tends to red like the color of the earth" is called ('A'afar).

This includes "Yellow-'A'afar".(Koraa' Al-Naml, 1989). Al-Asfar Al-'As`hab meaning (the reddish-yellow in color): Al-Ma'il ila Al-Baiyadh meaning (whitish-Yellow in color). It was said: Asfar Khalis meaning (pure yellow); and very close to white: "Asfar Fadhih"(Al-Qalqashandī, 1982). or "Asfar Dahabi meaning (golden yellow)" (Al-Nuwayrī, 2002).

Azraq (Blue): In the Arabic context, the color term Azraq (blue) is associated with the color of the eyes, water, and blade. Ibn as-Sikkit said: "Nasl Azraq baiyn Az-Zaraq (A clear blue blade), if it is a very clear. For the clear water, it is said: Azraq (blue). Zawraq meaning (boat): Is a type of ships." Here we see that the name of a boat in Arabic "Zawraq" was derived from Azraq (blue), the color of the clear water. Zurqat Al-Aiynain (blue eyes in color) means strong eyesight or for blue pupil color. Among this is "Zarqa al Yamama" (she was a blue-eyed Arab woman), is an example for Arabs in terms of good eyesight and visual acuity (Al-Thaalibi, n.d), Al-Aiyn Al-Zarqa (the blue eye) could mean the blue blind eye as a result of a disease. "It is when the black part of the eye covered with white," (Ibn Manzoor, 1993), so the eye becomes blue in color. In describing the eye, if its pupil is like glass, it is said: Zargaa meaning (a blue eye in color). (al-Dīnawarī, 1997). Regarding the variety of grapes in Taif, and in describing the color of one of its types, which is called "Umm Habib," Abu Hatim said: It is a grape with large clusters and large blue-black grains." (AlDīnawarī, 1997).

\section{The Semantic Principle of Classification of Colors in Arabic Language}

Cognitive linguistics has benefited from Rosch's findings in her thesis, which seeks to derive formal models of human memory about the concepts and their processes. She concluded that defining things strictly would not be congruent with the real psychological status. The objects that are perceived by the senses do not have strict and welldefined boundaries. Instead of there being a separation between conceptual areas, there are marginal areas between objects. To provide maximum information with minimum cognitive effort, the brain resort to categorize objects and concepts. So we see a great deal of variation in the way that colors are described by the Arabs. The Arabic language does not literally reflect what is happening in the retina of the eye. Rather, culture interacts with biological aspect in the cognition of colors and thus their names. Therefore, we see interference between the color terms green and black, red and black, blue and green, and yellow and black. 
Terms of many colors, with their different gradations, do not refer to specific objects or shapes in the world, but rather they refer to classified color categories. For example, the black color (Aswad) category terms refer to darkness, night and the unknown, which directly reflects what the Arab see in his environment. The color term Aswad (black), in the Arabic usage, is used to refer to a group of colors that were classified as dark colors.

The perception of colors goes through certain stages, depending on the daily stimuli that an Arab receives from his environment. Because daily stimuli exceed the human capacity due to their large number, the human decides the most important data/information to be aware of and based on this importance, the data/information be selected and then be perceived.

In the Arab experience, the selection of color terms is related to the colors of the most striking things in the Arab environment, which are the colors appear in the sky during the day or night, or that appear on the surface of the earth in sand or trees, or that appears on the Arabian desert animals, hence the second stage of perception, which is selection. After the selection of most prominent colors in the Arab environment, these colors and the similar or close colors to them are classified into categories indicate each other, and the perception of each color is associated with the first natural phenomenon that resembles it in color or from which the Arab borrowed the name of the color. Thus, we can interpret the semantic meanings of color terms based on the stimuli in the Arab environment that formed the common Arab experience in perceiving, naming and classifying color. Perception is a unified process that does not happen spontaneously, but rather passes through stages that allow the correct perception of stimuli and then choose from them what must be perceived.

Rosch's prototype theory is based on that all members of a category bear a family resemblance, even if in one feature, between the central meaning of the category and the concept of a prototype. In other words, the central exemplar of or the best central reference to dark colors is the color term Aswad (black). The idea of the prototype requires that the categories of dark colors are not composed of semantic components that are equidistant from the term Aswad (black) that combines them; Rather, the term Aswad (black) includes semantic components such as Qaatm (dark in color) or Daakn (deep in color), which are the best exemplars denoting to these colors than others. By contrast, the central exemplar of and the best central reference to light/bright colors is the color term Abiyadh (white).

The semantic meaning of the color term Abiyadh "white", for example, is not found in the speaker's mind only, but is a matter of the entire linguistic community. The concept of color has a social nature, as individuals in society share linguistic roles through agreed synonyms with each element of the use of terms of color in a given context. So, if the word (red) belongs to the color group of white and if the word (green) belongs to the color group of black, we should decide to present a typical description of these two colors that members of the linguistic community agree on. (Wittgenstein, 2007).

Ironically, we always claim that we reject racism against any group in society, and specifically against black people. But our language exposes our insides that we hide from others. This appears in our expression when we say "His heart is black", as a metaphor that describes a person who is full of hatred. Or when we say "His heart is white" as a metaphor for purity and soundness of intention. And we describe all bad deeds as black, "black file, black history, blacklisted...etc." And when we pray for good for someone, we say: "May God make your face white." And when we pray for evil against someone, we say: "May God make your face black." Our unintended language always reveals what we are trying to hide in our intended language. In my opinion, expressing hatred of the color black, or fear of it, may have been an indication of intellectual childhood. In other words, intellectual maturity makes us perceive colors as being more diverse and acceptable without fear of dark colors, or a great desire for bright colors. This is because that the wide perception of what we feel from the sensory perception of colors makes them more acceptable, and makes us more understanding the meanings that their words refer to away from the limited understanding of Aswad (black) and Abiyadh (white) as two terms referring to evil and good.

For an Arab, color metaphors appear in his perception of the concept of color, but do not appear in his naming of color itself. Color naming by the Arabs is related to the way they thinks about the color. The semantic meaning of the two color terms Aswad (black) and Abiyadh (white) in the Arabic language directly reflects the Arab ideas about night and day, darkness and light, the unknown and the known, fear and safety. The semantic meaning of the color terms Asfar (yellow), Akhdhar (green) and Azraq (blue) directly reflects what the Arabs see in the desert sands, the waters of the valleys, the colors of camels and trees, and the colors of people's skin and eyes. The Arab's metaphor of these twocolor terms (Aswad [black] and Abiyadh [white]) in particular is an essential tool with which he thinks and represents his vision of the world. These two-color metaphors are rooted in the Arab mentality and their appearance in linguistic use is one of the aspects of their realization.

\section{CONCLUSION}

What the eye perceives of colors are signs related to the human sensory experience. The color term does not have a specific and independent meaning, but rather its meaning is related to the total human experience. Managing the memories stored in our minds that are related to the perceptual dimensions of each color, enables us to contribute to improving the prevailing culture towards different colors. This is by guiding perception towards color-diversity and categorizing colors without taking a negative or racist attitude towards any color, and dealing with colors with 
intellectual maturity and categorizing them according to their diversity without making any childish judgments against any color based on traditional perceptual fears related to light or darkness in every society.

The concept of color term in Arabic language is generally related to human experience. The Arab forms a visual image of a color, which is then linked in the Arab mindset to the color name, and under each color are colors similar to it in hue. The main reference to the semantic classification here is night and day; the day is something Abiyadh (white), and the night is something Aswad (black). All colors are visible in the daytime. The black and white colors represent two fulcrums from which the gradations of colors start, and each color that is darker is called Aswad (black), while the color, which is more lighter/brighter, is called Abiyadh (white). Therefore, it cannot be argued that there is a unified concept of color perception in all languages. In the ancient Arabic language, the semantic meaning of color terms is a spatial connotation related to the Arab environment, but recently color names/terms in Arabic language have become more accurate and more diverse, and each color group/category has a specific name/term. Hopefully, this study will lead to further research on modern color terms in the field of cognitive semantics.

\section{REFERENCES}

[1] Abdul Amir, M. (2018). The Physiology of Colors: An Iconic Approach to the Qur'anic Discourse (in Arabic). Journal of AlUstad, 24, 32-55.

[2] Aharchaou, E. (2002). Cognitive anthropology and research on cultural constants (in Arabic). Journal of Human Sciences, University of Bahrain - College of Arts, 6, 270-281.

[3] Al-Biruni, M. (1990). Kitab Al-Jamahir Fi Marifat Al-Jawahir (The Book Most Comprehensive in Knowledge on Precious Stones) (in Arabic). Investigated by Salem Al-Karnouki. Riyadh, Al-Mutanabbi Bookshop.

[4] Al-Dīnawarī, I. (1997). al-Jarāthīm. Investigated by: Mohammed Al-Humaidi, $1^{\text {st }}$ Edition, Damascus, Ministry of Culture.

[5] Al-Isfahani, Abul-Qasim. (1992). Al-Mufradat fi Gharib al-Quran (a dictionary of Qur'anic terms) (in Arabic). Investigated by Safwan Adnan Al-Daoudi, $1^{\text {st }}$ edition, Damascus, Dar Al-Qalam, Al-Dar Al-Shamiya.

[6] Al-Jahiz, Amr. (n.d). Political Messages (in Arabic). Beirut, Dar al-Hilal.

[7] Al-Jamhi, Ibn Salam. (n.d). Tabaqat Fuhol ALshuara (Classes of great Poets) (in Arabic). Investigated by Mahmoud Mohammed Shaker, $1^{\text {st }}$ Edition, Jeddah, Dar Al-Madani.

[8] al-Jawhari, I. (1990). al-Șihāḥ Taj al-Lugha wa Sihah al-Arabiya (an Arabic dictionary) (in Arabic). Investigated by: Ahmed Abdel Ghafour Attar, $4^{\text {th }}$ Edition, Beirut, Dar Al-Ilm lil-Malayyin.

[9] Al-Katani, M. (1981). Similes from the poems of the people of Andalusia (in Arabic). Investigated by: Ihsan Abbas, $2^{\text {nd }}$ Edition, Cairo, Dar Al-Shorouq.

[10] Al-Muthanna, A. (1998). Explanation of the Naqa'id (Contradictions) of Jarir and Al Farazdaq (in Arabic). $1^{\text {st }}$ Edition, Abu Dhabi, The Cultural Foundation.

[11] Al-Nuwayrī, S. (2002). Nihayat al-'Araab fi funun al-Adab (in Arabic). $1^{\text {st }}$ Edition, Cairo, National Library and Documentation House.

[12] Al-Omari, A. (2002). Masālik al-abșār fĩ mamālik al-amșār (Paths of sight in the kingdoms of the regions) (in Arabic). $1^{\text {st }}$ Edition, Abu Dhabi, The Cultural Foundation.

[13] Al-Qalqashand̄̄, A. (1982). Șubḥ al-a'shā fị șinā'at al-inshā. ${ }^{\text {st }}$ Edition (in Arabic). Beirut, Dar al-Kutub al-Ilmiyya.

[14] Al-Qurashi, M. (1981). Jamharat Ash'ar al-Arab (The Gathering of the Arabs' Verses) (in Arabic). $1^{\text {st }}$ Edition, Giza City, Egypt Renaissance for publishing.

[15] al-Skafi, H. Color from physics to meaning (in Arabic). The Humanitarian Dialogue Foundation, (November-2018), Retrived in June, 2021 from: https://hdf-iq.org/.

[16] Al-Tabari, A. (2001). Jami al-Bayan on the Interpretation of the Verse of the Qur'an (in Arabic). Investigated by Abdullah bin Abdul-Mohsin Al-Turki, Dar Hajar, $1^{\text {st }}$ Edition, Part 10, p. 224.

[17] Al-Thaalibi, A. (n.d). Thimar al-qulub fi al-mudaf wa-al mansub (Fruits in the hearts and added attributed) (in Arabic). Investigated by: Mohammed Abu Al-Fadl, $1^{\text {st }}$ Edition, Dar Al-Maaref, Cairo.

[18] Al-Zubaidi, M. (1965). Taj al-Arus Min Jawahir al-Qamus (an Arabic Dictionary) (in Arabic). $2^{\text {nd }}$ Edition, Kuwait, Dar AlHedaya.

[19] Deutscher, G. (2015). Through the language glass: Why the world looks different in other languages (in Arabic). Translated by Hanan Abdul Mohsen Muzaffar, $1^{\text {st }}$ Edition, Kuwait, The World of Knowledge.

[20] Ghalim, M. (2010). Meaning and Referral in the Conceptual Framework (in Arabic). Journal of Linguistic Research, Institute for Studies and Research on Arabization, Rabat, Issues 27-28, pp. 7-28.

[21] Haji I,. \& Ibrahim, U. (2018). Development of collocation concept between western and Arab linguists (in Arabic). Journal of Linguistic and Literary Studies, International Islamic University Malaysia, Issue 2, pp. 32-52.

[22] Ibn Abd Rabbo, S. (1983). al-'Iqd al-Farīd (The Unique Necklace) (in Arabic). Beirut, Dar Al-Kutub Al-Ilmiyah.

[23] Ibn Faris. A. (1979). Language Standards (in Arabic). Investigated by Abdulsalam Haroun, Beirut, Dar al-Fikr.

[24] Ibn Manzoor. I. (1993). Lisan Al-Arab (in Arabic). $3^{\text {rd }}$ Edition, Beirut, Dar Sader.

[25] Ibn Saidah, A. (2000). Al-Muhkam wal Muhit Al A'azam (an Arabic dictionary) (in Arabic). Investigated by Abdulhameed Hindawi, $1^{\text {st }}$ Edition, Beirut, Dar Al-Kotob Al-Alami.

[26] John, L. (1987). Language and Linguistics (in Arabic). Translated by Mustafa Al-Tuni, $1^{\text {st }}$ Edition, Cairo, Dar Al-Nahda AlArabiya.

[27] Kahala, O. (1994). Dictionary of ancient and modern Arab tribes (in Arabic). $7^{\text {th }}$ Edition, Beirut, Ar-Resalah Publisher.

[28] Khalif, Y. (1959). The Vagabond Poets (ALsaalik) in the Pre-Islamic Era (in Arabic). $1^{\text {st }}$ Edition, Egypt, Dar Al-Maarif.

[29] Koraa' Al-Naml, A. (1989). al-Muntakhab min gharīb kalām al-'Arab (an Arabic dictionary) (in Arabic). Investigated by: Mohammed bin Ahmed Al-Omari, $1^{\text {st }}$ Edition, Mecca, Umm Al-Qura University. 
[30] Lakoff \& Johnson. (2009). Metaphors we live by: An introduction (in Arabic). Translated by Abdelmajid Jahfa, $2^{\text {nd }}$ Edition, Morocco, Dar Toubkal.

[31] Leyew, Z. (2016). The Description of Colour Terms in Ethiopian Languages. Eastern Africa Social Science Research Review, 32(2), 53-86

[32] Qutrub, M. (1985). Al-Azminah wa Talbiat Al-Jahiliah (in Arabic). Investigated by: Hazem Al-Damen, $2^{\text {nd }}$ Edition, Beirut, AlRisalah.

[33] Rosch, E. (2013). Principles of Categorization. University of California, pp. 27-48

[34] Wittgenstein, L. (2007). Philosophical investigations: An Introduction (in Arabic). Translated by: Abdelrazzaq Bannour, $1^{\text {st }}$ Edition, Beirut, The Arab Organization for Translation.

Jenan Al-Tamimi is an associate professor of Arabic Language at Prince Sattan Bin Abdulazziz University, Saudi Arabia. Her research interests include linguistics, cognitive linguistics, language, thinking, and digital communication. 